\title{
Prognosis of aortic valve disease following mitral valve surgery
}

\author{
Kinnaresh Baria, Jignesh Kothari, Divyesh Rathod \\ Department of Cardiovascular and Thoracic Surgery, U.N.Mehta Institute of Cardiology and Research Center, \\ Gujarat, India
}

Kardiochirurgia i Torakochirurgia Polska 2019; 16 (2): 65-68

\begin{abstract}
Introduction: Little is known about the course of aortic valve disease in patients undergoing mitral valve surgery for rheumatic mitral valve disease. In addition, there are no guidelines regarding the appropriate treatment of mild aortic valve disease while replacing the mitral valve.

Aim: To evaluate the long-term outcome of aortic valve disease and the need for aortic valve surgery in patients with rheumatic mitral valve disease who underwent mitral valve surgery.

Material and methods: Twenty patients ( 6 male, 14 female; mean age: 23.4 years, range: 14-41) were followed after mitral valve surgery for a mean period of 14 years. All patients had rheumatic heart disease. Aortic valve function was assessed preoperatively by transthoracic echocardiography and during follow-up.

Results: At the time of mitral valve surgery, 11 (55\%) patients had aortic valve disease with aortic regurgitation. Nine (45\%) patients had no evidence of aortic valve disease. At second surgery, all patients had aortic valve disease (either pure regurgitation or with stenosis). Most had mild disease at the time of mitral valve surgery. Aortic valve replacement was needed after a mean period of 14.1 years (range: 3-26 years). Conclusions: In patients with rheumatic heart disease, a noticeable number of patients have mild aortic valve disease at the time of mitral valve surgery. Only a few progress to severe disease, and aortic valve replacement is rarely needed after a long follow-up period.
\end{abstract}

Key words: aortic valve, rheumatic valve disease.

\section{Introduction}

A noticeable percentage of patients who require mitral valve replacement present with a coexisting pathology of the aortic valve (AV). Rheumatic heart disease remains the major cause for combined disease [1]. Early series found

\section{Streszczenie}

Wprowadzenie: Niewiele wiadomo na temat przebiegu choroby zastawki aortalnej u pacjentów poddawanych operacji zastawki mitralnej z powodu jej choroby reumatycznej. Ponadto nie istnieją wytyczne dotyczące właściwego leczenia łagodnej choroby zastawki aortalnej przy wymianie zastawki mitralnej. Cel: Ocena odległych skutków choroby zastawki aortalnej i konieczności wykonania operacji zastawki aortalnej u pacjentów, którzy przeszli operację zastawki mitralnej z powodu jej choroby reumatycznej.

Materiał i metody: Obserwacją objęto 20 pacjentów (6 mężczyzn, 14 kobiet; średnia wieku: 23,4 roku, zakres: 14-41 lat) przez okres średnio 14 lat. U wszystkich pacjentów występowała choroba reumatyczna serca. Ocenę funkcji zastawki aortalnej przeprowadzono za pomocą echokardiografii przezklatkowej przed operacją i w okresie obserwacji.

Wyniki: W chwili przeprowadzania operacji zastawki mitralnej u 11 (55\%) pacjentów występowała choroba zastawki aortalnej z niedomykalnością. U 9 (45\%) pacjentów nie stwierdzono objawów choroby zastawki aortalnej. Przy drugim zabiegu u wszystkich pacjentów występowała choroba zastawki aortalnej (niedomykalność albo zwężenie). U większości w chwili operacji zastawki mitralnej choroba miała łagodny charakter. Wymiana zastawki aortalnej była konieczna po upływie średnio 14,1 roku (zakres: 3-26 lat).

Wnioski: Wielu pacjentów z chorobą reumatyczną serca ma łagodną formę choroby zastawki aortalnej w chwili operacji zastawki mitralnej. Jedynie u niewielu pacjentów choroba przybiera postać poważną, a konieczność wymiany zastawki aortalnej występuje rzadko i po upływie długiego czasu.

Słowa kluczowe: zastawka aortalna, choroba reumatyczna zastawki.

that one-third of rheumatic hearts exhibited involvement of both mitral and AV. The rate rose to $99 \%$ when the followup period was increased to 20 years [2-4]. The treatment of choice in those cases in which one of the valves is less than moderately affected is questionable. Since double valve re-

Address for correspondence: Jignesh Kothari, Department of Cardiovascular and Thoracic Surgery, U.N.Mehta Institute of Cardiology and Research Center, 380016 Gujarat, India, e-mail: jvks20@yahoo.com Received: 21.02.2019, accepted: 30.05.2019. 
placement is more often associated with higher risk and poorer long-term survival than replacement of either of the two valves alone [5], a higher threshold for combined aortic and mitral valve replacement is required. In the absence of a stringent policy, the decision to replace more than one valve is often made by the surgeon during the operation.

For rational management of multivalve involvement, we reviewed our experience with patients with rheumatic heart disease who underwent mitral valve replacement and were followed for an average of 14.1 years.

\section{Aim}

The goal of this study was to evaluate the course of AV disease after mitral valve (MV) surgery, including the need for further AV surgery.

\section{Material and methods \\ Study patients}

Between 2013 and 2016, a total of 20 patients underwent AV surgery in our cardiothoracic surgery division with a history of previous MV surgery. Rheumatic valve disease

Table I. Demographic and clinical characteristics of the patients

\begin{tabular}{lc} 
Characteristics & Result \\
\hline Mender: & $6(30 \%)$ \\
\hline Male & $14(70 \%)$ \\
\hline Age at mitral valve surgery [years]: & \\
\hline Mean \pm SD & $23.4 \pm 9.11$ \\
\hline Range & $14-41$ \\
\hline Type of surgery: & $16(80 \%)$ \\
\hline Mitral valve replacement & $4(20 \%)$ \\
\hline Commissurotomy & $14.1 \pm 8.4$ \\
\hline Duration of follow-up: & $3-26$ \\
\hline Mean \pm SD & 8 \\
\hline Range & 4 \\
\hline Number of patients during follow-up: & 8 \\
\hline$\leq 5$ years & \\
\hline$\leq 10$ years & \\
\hline$\leq 15$ years
\end{tabular}

Table II. Aortic valve disease at the time of mitral valve surgery and at follow-up

\begin{tabular}{lcc} 
Variable & Entry & Follow-up \\
No AVD & 9 & - \\
\hline AVD: & 11 & 20 \\
\hline Pure AS & - & 3 \\
\hline Pure AR: & 11 & \\
\cline { 2 - 3 } Mild & 11 & 11 \\
\hline Severe & - & 6 \\
\hline AS + AR & & \\
\hline
\end{tabular}

was present in all patients. Each patient was evaluated by postoperative transthoracic Doppler echocardiography examinations (for at least 1 year after the surgery). Clinical data regarding age, gender, heart rhythm, New York Heart Association functional class and presence of concomitant medical problems (coronary heart disease, diabetes, hypertension, hyperlipidemia and chronic renal failure) were obtained from the hospital records.

\section{Echocardiographic analysis}

Echocardiographic studies were performed in a standard manner and included the parasternal long and short-axis views and the two-, four- and five-chamber and apical longaxis views. Mean and peak transaortic gradients were calculated with the modified Bernoulli equation [6] using continuous-wave Doppler recordings. The AV area was computed with the continuity equation [7] using standard methods when systolic function of the left ventricle was decreased. In the presence of normal left ventricle systolic function (estimated qualitatively and by measurement of fractional shortening above $30 \%$ ) the mean gradient was used to define the severity of aortic stenosis (AS) (mild $<20 \mathrm{~mm} \mathrm{Hg}$, moderate 20-40 mm Hg, and severe > $40 \mathrm{~mm} \mathrm{Hg}$ ). In cases of systolic left ventricular dysfunction, an AV area of $1.5 \mathrm{~cm}^{2}$ or more was considered mild AS; 1.1 to $1.5 \mathrm{~cm}^{2}$, moderate; and $1.0 \mathrm{~cm}^{2}$ or less, severe [8]. Aortic regurgitation grade was estimated by integrating the continuous wave Doppler signal [9] and the color flow mapping, as previously described $[10,11]$. Imaging was performed using commercially available ultrasound systems (GE Vivid I, GE Vivid E and Philips HD11XE) and interpreted by a cardiologist skilled in echocardiography.

\section{Results}

The average follow-up period for the 20 patients was 14.1 years (range: $3-26$ years, median: 13 years) (Table I).

All the patients had rheumatic heart disease. Ten patients had mitral regurgitation, 8 had mitral stenosis and 2 patients had combined mitral stenosis and regurgitation. Mitral valve replacement was performed in 16, commissurotomy in 4 (Table I). These patients had either normal AV or mild disease at the time of the first mitral valve surgery (based on preoperative echocardiography).

At the time of mitral valve surgery, 11 (55\%) patients had AV disease with mild aortic regurgitation (AR). Nine (45\%) patients had no evidence of AV disease (Table II).

At the second surgery, all patients had AV disease (either pure regurgitation or stenosis; AS with AR) (Table II). Six had both AS and AR (only a single case of mild AS with severe AR and 5 cases of severe AS with severe AR). Eleven had severe AR while severe AS was noted in 3 patients. According to the clinical evaluation at the end of the follow-up period, 18 patients had functional class (Fc) III and 2 had Fc IV.

From the time of mitral valve surgery, patients with mild AR progressed to severe AR over a mean follow-up period of 14.1 years (range: 3-26 years, median: 13 ). 
Of the 9 patients without AV disease at the time of mitral valve surgery, two had combined lesions, i.e. AS with $A R$, and the rest had $A R$ during the follow-up period.

Of the 4 cases of AS, 1 was mild and 3 were severe.

After a median of 13 years of follow-up (range: 3-26 years), all patients of the cohort required surgery for moderate to severe AV disease. All were graded as NYHA functional class III-IV. In all patients the mitral valve prosthesis was functioning normally.

\section{Discussion}

Patients having rheumatic heart disease and mild AV disease at the time of mitral valve surgery seldom develop hemodynamically significant $\mathrm{AV}$ disease and rarely require AV surgery after a long follow-up period.

A substantial number of patients with valvular disease have multivalvular involvement. Prospective studies on patients with rheumatic heart disease have demonstrated combined aortic and mitral valve disease in up to $99 \%$ over a period exceeding 20 years [2-4].

The high incidence of multivalvular involvement in patients who undergo mitral valve surgery has raised the concern for AV replacement at the same time; this decision is very difficult when the AV disease is moderate or less than moderate. The other route is to carefully follow these patients with the consideration that some may require $\mathrm{AV}$ surgery later. Although this option may potentially increase patient morbidity and mortality, it avoids the short- and long-term risks of an unnecessary dual valve replacement when the AV disease is stable.

To solve this dilemma, the clinician must consider the pattern of progression of AV disease, which varies with its etiology. Aortic stenosis may progress more rapidly in patients with degenerative disease than those with rheumatic or congenital disease [12-14]. Reports on the longterm evolution of AS based on cardiac catheterization and Doppler studies have demonstrated an annual increment of 0.1 to $0.14 \mathrm{~cm}^{2}$ in AV narrowing [12, 15-19] and an annual increase of $8.3 \mathrm{~mm} \mathrm{Hg}$ in the peak gradient [15]. Brener et al. [15] found that disease progression was faster in the patients who had the mildest stenosis at presentation, progressive left ventricular hypertrophy or concomitant mitral regurgitation that worsened over time. The progression rate may also be related to the presence of a coexisting coronary disease or progressive leaflet calcification [20].

The linearity or nonlinearity of AS progression is multifactorial and may also influence the management policy. Thoreau et al. observed a linear pattern of progression when the AV area was large and a slower progression rate when the severity of stenosis increased [20]. Although this finding was confirmed by others [21-23], larger studies are needed to establish its clinical relevance.

Data on the rate of progression of chronic AR are also limited. Recently, Padial et al. [24] studied 127 patients with variable degrees of chronic AR. After $59 \pm 21$ months of follow-up, the regurgitation increased in 30\%; of these $25 \%$ had previously mild disease and $44 \%$ had previously moderate disease. These findings show that chronic AR is a progressive disease after several decades.

Unlike the natural history of isolated AV disease or that associated with coronary heart disease, the natural history and the progression pattern of AV disease in patients undergoing mitral valve surgery are unknown. It may be that the repair or replacement of the mitral valve may change the flow characteristics near the AV. A different course of $\mathrm{AV}$ disease in the presence of mitral valve surgery might be expected.

In the present study, we found that AR and AS have a slow rate of progression after mitral valve surgery, similar to that in patients with rheumatic AV disease without mitral valve surgery. Furthermore, AV replacement in the few cases in which it was needed was performed on average 14 years after the original mitral valve surgery. Transcatheter aortic valve implantation would not be a good option for a young patient as compared to surgical aortic valve replacement.

Our study is limited by the limited size of the study population.

Because the follow-up period took time, the changes in echocardiographic methods and improvement in equipment must be considered. Nevertheless, we believe that our findings will be substantiated as our experience increases.

\section{Conclusions}

Patients with mild AV disease at the time of mitral valve surgery develop hemodynamically significant AV disease over a long follow-up period. The minor progression in the AV disease over a long period of time should be considered in sparing AV disease. This is true for both AS and AR.

\section{Disclosure}

The authors report no conflict of interest.

\section{References}

1. Roberts WC, Virmani R. Aschoff bodies at necropsy in valvular heart disease. Circulation 1978; 57: 803-815.

2. Clausen BJ. Rheumatic heart disease: an analysis of 796 cases. Am Heart J 1940; 20: 454-474.

3. Wilson MG, Lubschez R. Longevity in rheumatic fever. JAMA 1948; 138: 794 798.

4. Bland EF, Jones TD. Rheumatic fever and rheumatic heart disease: a twenty year report on 1,000 patients followed since childhood. Circulation 1951; 4: 836-843.

5. Kirklin JW, Barratt-Boyes BG. Combined aortic and mitral valve disease with or without tricuspid valve disease. In: Cardiac Surgery. Kirklin JW (ed.). $2^{\text {nd }}$ edn. Churchill-Livingstone, New York 1993; 573-588.

6. Yeager M, Yock PG, Popp RL. Comparison of Doppler-derived pressure gradient to that determined at cardiac catheterization in adults with aortic valve stenosis: implication for management. Am J Cardiol 1986; 57: 644-648.

7. Perakis AC, Montarello JK, Rosenthal E, Boyd EG, Yates AK, Deverall PB, Curry PV, Sowton E. In vitro measurement of stenotic human aortic valve orifice area in a pulsatile flow model. Validation of the continuity equation. Eur Heart J 1990; 11: 492-499.

8. Rahimtoola SH. Aortic valve stenosis. In: Atlas of Heart Disease. Vol. 11 Braunwald E (ed.). C.V. Mosby, St. Louis 1977; 6.01-6.02.

9. Grayburn PA, Handshoe R, Smith MD, Harrison MR, Demaria AN. Quantitative assessment of the hemodynamic consequences of aortic regurgitation 
by means of continuous wave Doppler recordings. J Am Coll Cardiol 1987; 10: $135-141$.

10. Bouchard A, Yock P, Schiller NB, Blumlein S, Botvinick EH, Greenberg B, Cheitlin M, Massie BM. Value of color Doppler estimation of regurgitation volume in patients with chronic aortic insufficiency. Am Heart J 1989; 117: 1099-1105.

11. Reynolds T, Abate J, Tenney A, Warner MG. The JH/LVOH method in the quantification of aortic regurgitation: how the cardiac sonographer may avoid an important potential pitfall. J Am Soc Echocardiogr 1991; 4: 105-108.

12. Wagner S, Selzer A. Patterns of progression of aortic stenosis: a longitudinal hemodynamic study. Circulation 1982; 65: 709-712.

13. Selzer A. Changing aspects of natural history of valvular aortic stenosis. N Engl J Med 1987; 317: 91-98.

14. Kennedy KD, Nishimura RA, Holmes DR Jr, Bailey KR. Natural history of moderate aortic stenosis. J Am Coll Cardiol 1991; 17: 313-319.

15. Brener SJ, Duffy Cl, Thomas JD, Stewart WJ. Progression of aortic stenosis in 394 patients: relation to changes in myocardial and mitral valve dysfunction. J Am Coll Cardiol 1995; 25: 3305-3310.

16. Faggiano P, Ghizzoni G, Sorgagto A, Sabatini T, Simoncelli U, Gardini A, Rusconi C. Rate of progression of valvular aortic stenosis in adults. Am J Cardiol 1992; 70: 229-233.
17. Bogart DB, Murphy BL, Wong BY, Pugh DM, Dunn MI. Progression of aortic stenosis. Chest 1979; 76: 391-396.

18. Ng AS, Holmes DR Jr, Smith HC, Connolly DC, Hynes JK, Ilstrup DM, Danielson GK. Hemodynamic progression of adult valvular aortic stenosis. Cathet Cardiovasc Diagn 1986; 12: 1445-1550.

19. Davies SW, Gershlick AH, Baloon R. Progression of valvular aortic stenosis: a long-term retrospective study. Eur Heart J 1991; 12: 10-14.

20. Thoreau WA, Siu SC, Thoreau DH, Vandervort DM, Thomas JD, Weyman AE. The rate and pattern of change in valve area in aortic stenosis: long-term Doppler follow-up (abstr). J Am Coll Cardiol 1992; 19: 331A.

21. Akins CW. Long term results with the Medtronic-Hall valvular prosthesis. Ann Thorac Surg 1996; 61: 806-813.

22. Davies SW. Progression of aortic stenosis. Role of age and concomitant coronary artery disease (letter). Chest 1994; 107: 1902.

23. Faggiano P, Aurigemma GP, Rusconi C, Gaasch WH. Progression of valvular aortic stenosis in adults: literature review and clinical implication. Am Heart J 1996; 132: 408-417.

24. Padial LR, Oliver A, Vivaldi M, Sagie A, Freitas N, Weyman AE, Levine RA. Doppler echocardiographic assessment of progression of aortic regurgitation. Am J Cardiol 1997; 80: 306-314. 